The Open Microbiology Journal
CrossMark
Content list available at: www.benthamopen.com/TOMICROJ/
DOI: $10.2174 / 1874285801711010179$

RESEARCH ARTICLE

\title{
Antimicrobial Activity of Cultivable Endophytic Fungi Associated with Hancornia Speciosa Gomes Bark
}

Mardonny Bruno de Oliveira Chagas ${ }^{1}$, Irailton Prazeres dos Santos ${ }^{1}$, Luis Claudio Nascimento da Silva $^{2}$, Maria Tereza dos Santos Correia ${ }^{1}$, Janete Magali de Araújo ${ }^{3}$, Marilene da Silva Cavalcanti ${ }^{4}$ and Vera Lucia de Menezes Lima,

${ }^{I}$ Departamento de Bioquímica, Universidade Federal de Pernambuco, Av. Prof. Moraes Rego, S/No, Cidade Universitária, Recife, PE, 50670-420, Brazil

${ }^{2}$ Programa de Pós-graduação em Biologia Parasitária, Universidade Ceuma, Rua Josué Montello, São Luís, MA, 65075-120, Brazil

${ }^{3}$ Departamento de Antibióticos, Universidade Federal de Pernambuco, Av. Nelson Chaves, S/N, Cidade Universitária, Recife, PE, 50670-420, Brazil

${ }^{4}$ Departamento de Micologia, Universidade Federal de Pernambuco, Av. Nelson Chaves, Cidade Universitária, S/N, Recife, PE, 50670-420, Brazil

Received: April 13, 2017

Revised: August 01, 2017

Accepted: August 13, 2017

Abstract:

Introduction:

In this study, we evaluated the antimicrobial potential of cultivable endophytic fungi associated with Hancornia speciosa Gomes stem bark.

\section{Methods and Materials:}

Plant samples were collected in rainy (July 2010) and dry (January 2011) seasons. In total, 116 endophytic fungi strains were isolated from 90 fragments (64.4\% frequency of colonization). Higher fungi frequency was observed in the rainy season (84.4\%). The strains were grouped into 14 species; the most frequent were Phoma cava (13.8\%), Colletotrichum gloeosporioides (12.1\%), and Lasiodiplodia theobromae (11.2\%). Fungal diversity was similar in both the seasons. Among the 116 strains, 39 (33.6\%) showed antimicrobial activity in preliminary screening. The ten most active isolates were subjected to semi-solid fermentation using rice or corn as substrates. Methanolic extracts were obtained from each fermentation medium and the minimum inhibitory (MIC) and minimum microbicide concentrations (MMC) were determined.

\section{Results:}

The best antimicrobial results (MIC $<100 \mu \mathrm{g} / \mathrm{mL}$ ) were observed for fungi strains grown in rice medium: Aspergillus niger FHS061 against Proteus mirabilis (MIC $=19 \mu \mathrm{g} / \mathrm{mL}$ ) and Staphylococcus aureus $(\mathrm{MIC}=39 \mu \mathrm{g} / \mathrm{mL}$ ). These strains also showed good results when cultivated in corn medium against $P$. mirabilis $(\mathrm{MIC}=78 \mu \mathrm{g} / \mathrm{mL})$.

\section{Conclusion:}

Thus, the stem bark of $H$. speciosa harbors diverse endophytic fungi with antimicrobial potential.

Keywords: Fungi diversity, Natural compounds, Semi-solid fermentation, Aspergillus niger, Fusarium solani, Proteus mirabilis.

\footnotetext{
* Address correspondence to this author at the Departamento de Bioquímica, Universidade Federal de Pernambuco, Av. Prof. Moraes Rego, S/N ${ }^{\circ}$, Cidade Universitária, Recife, PE, 50670-420, Brazil; Tel: +5581-32718540; Fax: +5581-32718541; E-mail: lima.vera.ufpe@gmail.com
} 


\section{INTRODUCTION}

Drug resistance is a serious problem worldwide, particularly in hospital environments, contributing to the resurgence of more complex infections and deleterious socioeconomic effects [1 - 3]. This situation is exacerbated by the increasing number of immuno-compromised patients (elderly subjects with chronic diseases, etc.), continuous flow of travelers and molecular mechanisms of resistance acquisition [4 - 6]. These factors make essential the search for new and effective antimicrobial agentes. Different sources of natural compounds should be studied in order to exploit the chemical diversity found in nature. Plants can serve as reservoirs for numerous microorganisms classified depending on the locus at which they are found and their functions in the plant. For example, microorganisms known as endophytes colonize plant tissue without causing any apparent symptoms and damages $[7,8]$.

Endophyte research has stimulated the interest of the scientific community, as these microorganisms represent an important genetic source with the ability to produce metabolites with diverse biotechnological applications [7 - 9]. Several studies have shown that the colonization and distribution of the endophytic population in plant tissues are regulated by different properties such as environmental factors, microorganism-plant interactions and endophyte community interactions $[10,11]$. Due this extensive network of stimuli that regulates the metabolic capacity of endophytic fungi, these microorganisms are excellent targets in the search for compounds with antimicrobial activity, and numerous examples of identified antimicrobials compounds of endophytic fungi have been reported [7].

The pharmacological properties of plants used in folk medicine have been extensively studied, and increasing attention has been given to the biotic components present in these plants [7, 8, 11 - 13]. Hancornia speciosa Gomes (Apocynaceae), a plant native to Brazil and popularly known as mangabeira, is commonly found in the Amazon Rainforest, Cerrado, and Caatinga biomes $[14,15]$. This plant has been used to treat various pathologies; some of these properties have been scientifically confirmed such as its antimicrobial [16], antihypertensive [17], antiulcerous [18], antidiabetic [19], anticancer [20], wound healing [21] and anti-inflammatory actions [22, 23]. A recent paper showed that this plant has potential activity against Alzheimer's Disease [24]. However, the microbiota of this plant has not been widely examined, and only one study has evaluated the bacterial community associated with trunk latex [14]. The stem bark of this plant shows antimicrobial activity [16], which was also confirmed by preliminary data from our group (results not published). In this study, we evaluated the antimicrobial activity of endophytic fungi isolated from $H$. speciosa stem bark in two different climatic periods: rainy season (RS) and dry season (DS).

\section{MATERIAL AND METHODS}

Plant samples were collected during the rainy (July 2010) and dry (January 2011) seasons from the Recife coastal region (08²4'334"S, 34⒐'384”W), Pernambuco, Brazil. At each sampling period, three samples of stem bark from five healthy specimens of $H$. speciosa were randomly collected, and processed in the Department of Mycology, Federal University of Pernambuco (UFPE).

\subsection{Isolation of Endophytic Fungi}

Initially, healthy samples of stem barks of $H$. speciosa were superficially sterilized to eliminate epiphytic microorganisms. The endophytic fungi were isolated from fragments of stem barks $\left(1 \mathrm{~cm}^{2}\right)$ using Petri dishes containing potato dextrose agar (PDA; containing $200 \mathrm{~g} / \mathrm{L}$ potato, $20 \mathrm{~g} / \mathrm{L}$ dextrose, and $15 \mathrm{~g} / \mathrm{L}$ agar, $\mathrm{pH}$ 6.0). The whole procedure is comprehensively explained in Santos et al. [11].

\subsection{Identification of Endophytic Fungi}

Endophytic fungi from stem barks of $H$. speciosa were identified through macroscopic and microscopic evaluation using the instructions previously reported [25 - 30]. For this, each colony was grown in PDA, Sabouraud-dextrose agar (SDA), Czapek agar and malt extract agar. Strains showing antimicrobial activity were deposited in the URM Culture Collection (WDCM604) of UFPE. The absolute frequency (f) was estimated as the total number of endophyte isolates, while the relative frequency (rf) was the number of endophytes of each species divided by the total number of endophytic fungi. The rate of colonization was estimated as the total number of fragments of leaves colonized by fungi divided by the total number of fragments used for the isolation of endophytes. The number of isolates in each season was used to determine diversity indices: richness $(\mathrm{S})$, evenness $\left(\mathrm{J}^{\prime}\right)$, the Simpson $\left(\mathrm{D}^{\prime}\right)$, and Shannon-Wiener $\left(\mathrm{H}^{\prime}\right)[11]$. 


\subsection{Test Microorganisms}

The antimicrobial activity of endophytic fungi was assayed against test microorganisms provided by the URM Culture Collection and UFPEDA Culture Collection (Department of Antibiotics; UFPE). The following fungi were tested: Candida albicans URM-5825, Candida krusei UFPEDA-1002, Candida tropicalis URM-5871, Malassezia furfur URM-4220, Staphylococcus aureus UFPEDA-02, Bacillus subtilis UFPEDA-86, Escherichia coli UFPEDA-224, Klebsiella pneumoniae UFPEDA-396, Pseudomonas aeruginosa UFPEDA-416, and Proteus mirabilis UFPEDA-767.

\subsection{Antimicrobial Screening}

All endophytic fungi isolated from stem barks of $H$. speciosa were subjected to a preliminary agar diffusion assay as described by Dos Santos et al. [12] using Petri dishes previously spread with bacteria (Müller-Hinton agar) and fungi [Sabouraud dextrose agar (SDA) for Candida strains and SDA supplemented with $0.5 \%$ (SDA+) olive oil for $M$. furfur]. After incubation $\left(37^{\circ} \mathrm{C}\right.$ for $24 \mathrm{~h}$ for bacteria; and at $30^{\circ} \mathrm{C}$ for $48 \mathrm{~h}$ for fungi), the antimicrobial activity was assayed by measuring inhibition diameter zones (IDZ).

\subsection{Semi-Solid-State Fermentation of Most Active Fungi in Semisolid Medium}

The endophytic fungi showing the highest antimicrobial activity were cultured in SDA medium at $28 \pm 2^{\circ} \mathrm{C}$. After 7 days, five blocks $(5 \mathrm{~mm})$ were transferred to Erlenmeyer flasks $(1000 \mathrm{~mL})$ containing rice or corn semisolid media (media preparation was performed as previously described [12]. Each fungus was statically cultivated at room temperature $\left(28 \pm 2{ }^{\circ} \mathrm{C}\right)$. After 30 days, methanolic extracts were prepared as described by Dos Santos et al. [12], dissolved in dimethyl sulfoxide (DMSO) and stored at $-20^{\circ} \mathrm{C}$ until use.

\subsection{Determination of Minimum Inhibitory and Minimum Microbicide Concentrations}

Minimum inhibitory concentration (MIC) and minimum microbicide concentration (MMC) were determined by broth microdilution method using specific media (Müller-Hinton agar, SBA or SBA+) as described by Dos Santos et al. [12]. Each extract (in 10\% DMSO) was tested in concentrations ranging from $9.76 \mu \mathrm{g} / \mathrm{mL}$ to $5000 \mu \mathrm{g} / \mathrm{mL}$. Each assay was conducted in triplicate.

\section{STATISTICAL ANALYSIS}

All statistical analysis was performed by GraphPad Prism using one-way analysis of variance (ANOVA) and Tukey tests. Data were considered significantly different when $p<0.05$. Pearson coefficient $(\rho)$ was used to calculate correlation between the data.

\section{RESULTS AND DISCUSSION}

\subsection{Endophytic Fungi Isolated from the Stem Bark of $H$. Speciosa}

In total, 116 isolates of endophytic fungi were obtained from the 180 fragments analyzed (90 in each period of the year) (Table 1). These results correspond to a total frequency of colonization (FC) of 64.4\%. Regarding the period of the year, 40 isolates were obtained during the dry season (FC of 44.4\%), while 76 were obtained during the rainy season (FC of $84.4 \%$ ). The isolated endophytic fungi were grouped into 14 species: Trichoderma harzianum (9.5\%), Phomopsis archeri (8.7\%), Aspergillus niger (6.9\%), Penicillium fellutanum (6.9\%), Nigrospora sphaerica (6\%), and Fusarium solani (5.2\%). The occurrence of occasional species was also observed in this study, as represented by Aspergillus flavus, Fusarium lateritium, Tritirachium oryzae, Cladosporium cladosporioides, and Marianea elegans.

Notably, some species of fungi were exclusively isolated during the dry period (C. cladosporioides and M. elegans) or rainy season ( $F$. lateritium, $F$. solani, $P$. fellutanum, $P$. archeri, and $T$. oryzae). The species $P$. cava, $C$. gloeosporioides, and L. theobromae showed higher frequencies of colonization. Only a few species were found more frequently compared to the others $[31,32]$. The most frequently occurring species are likely those that have a greater affinity to the host plant and perform essential functions such as protection against pathogens [33, 34]. The genera Aspergillus, Fusarium, Nigrospora, Penicillium, Phomopsis, and Trichoderma isolated in this work are frequently reported as endophytes of tropical and subtropical plants [35]. 
Table 1. Endophytic fungi isolated from $H$. speciosa bark in rainy and dry seasons.

\begin{tabular}{|c|c|c|c|c|c|c|}
\hline \multirow{2}{*}{ Endophytic fungi } & \multicolumn{2}{|c|}{ RS } & \multicolumn{2}{|c|}{ DS } & \multicolumn{2}{|c|}{ Total } \\
\hline & f & rf & f & rf & f & rf \\
\hline Aspergillus flavus Link & 4 & 5.3 & 1 & 2.5 & 5 & 4.3 \\
\hline Aspergillus niger Tiegh & 5 & 6.6 & 3 & 7.5 & 8 & 6.9 \\
\hline Cladosporium cladosporioides (Fresen.) G.A. de Vries & - & - & 3 & 7.5 & 3 & 2.6 \\
\hline Colletotrichum gloeosporioides (Penz.) Penz. \& Sacc. & 6 & 7.9 & 8 & 20 & 14 & 12.1 \\
\hline Fusarium lateritium Nees & 4 & 5.3 & - & - & 4 & 3.4 \\
\hline Fusarium solani (Mart.) Sacc. & 6 & 7.9 & - & - & 6 & 5.2 \\
\hline Lasiodiplodia theobromae (Pat.) Grif. Maubl. & 8 & 10.5 & 5 & 12.5 & 13 & 11.2 \\
\hline Mariannaea elegans G. Arnaud & - & - & 2 & 5 & 2 & 1.7 \\
\hline Mycelia sterilia & 3 & 3.9 & 2 & 5 & 5 & 4.3 \\
\hline Nigrospora sphaerica (Sacc.) Mason. & 4 & 5.3 & 3 & 7.5 & 7 & 6.0 \\
\hline Penicillium fellutanum Biourge & 8 & 10.5 & - & - & 8 & 6.9 \\
\hline Phoma cava Schulzer & 6 & 7.9 & 10 & 25 & 16 & 13.8 \\
\hline Phomopsis archeri B. Sutton. & 10 & 13.1 & - & - & 10 & 8.7 \\
\hline Trichoderma harzianum Rifai. & 8 & 10.5 & 3 & 7.5 & 11 & 9.5 \\
\hline Tritirachium oryzae (Vincens) de Hoog & 4 & 5.3 & - & - & 4 & 3.4 \\
\hline Total & \multicolumn{2}{|c|}{76} & \multicolumn{2}{|c|}{40} & \multicolumn{2}{|c|}{116} \\
\hline
\end{tabular}

RS: Rainy season; DS: Dry season; f: absolute frequency; rf: relative frequency.

The lowest colonization rates were observed for C. cladosporioides, M. elegans, and T. oryzae. In general, these species can be classified as occasional, as they were represented by a few isolates [32]. In addition, endophytic isolates that did not develop reproductive structures necessary for identification after a certain culture period were also isolated. These isolates were classified as Mycelia sterilia [12, 32, 36, 37] (Table 1).

We observed that the frequency of isolated endophytes in the rainy season was higher than in the dry period. This results may be related to some aspects such as (i) increase of spore dissemination promoted by rain; (ii) facilitation of spore germination by high humidity [38]. Numerous environmental factors are known to influence the frequency of colonization in a plant, including climatic conditions and soil composition at the collection site [10, 11, 38]. Other factors such as fog, rainfall, and dew also play important roles in endophyte diversity, as they can serve as vehicles for fungal spores that penetrate plant tissues and colonize the plant [39].

The diversity indices of isolated fungal populations in each period are shown in Table 2 . The richness (S) values were 1.491 and 1.581 for the rainy season (RS) and dry season (DS), respectively. The RS showed higher values of Shannon-Wiener and evenness indices ( $\mathrm{H}^{\prime}: 2.506$ and J: 0.977) than the DS ( $\mathrm{H}^{\prime}: 2.097$ and J: 0.911). In contrast, the Simpson index was higher during the DS than RS $(D=0.146$ and 0.086 , respectively). Furthermore, a weak correlation was observed when the number of strains isolated for each species was analyzed $(\rho=0.053)$; a Sørensen-Dice coefficient of 0.696 was found between both seasons. The richness (S) values were 1.491 and 1.581 for the RS and DS, respectively. The RS showed higher values of Shannon-Wiener and evenness indices $\left(\mathrm{H}^{\prime}: 2.506\right.$ and J: 0.977$)$ than the DS (H': 2.097 and J: 0.911). In contrast, the Simpson index was higher during the DS than the RS (D = 0.146 and 0.086, respectively). These results showed that although different relative frequencies were observed during each season, species diversity was similar.

Table 2. Diversity, evenness and species richness of endophytic fungi isolated from $\mathrm{H}$. speciosa bark in rainy and dry seasons.

\begin{tabular}{|c|c|c|}
\hline Diversity indices & Rainy Season & Dry Season \\
\hline Shannon-Wiener index $\left(H^{\prime}\right)$ & 2.506 & 2.097 \\
\hline Hmax & 2.565 & 2.303 \\
\hline Evenness $(J)$ & 0.977 & 0.911 \\
\hline Simpson index $(D)$ & 1.491 & 0.146 \\
\hline Richness & 1.581 & \\
\hline
\end{tabular}




\subsection{Screening of Antimicrobial Activity}

Endophytic fungi have a higher potential to produce a wide variety of bioactive molecules that belong to various structural classes (such as alkaloids, peptides, steroids, terpenoids, phenols, quinones, and flavonoids). These chemical variety of fungi metabolites is associated with the inhibition of a wide variety of pathogenic microorganisms [7 - 9, 12, $13]$.

We examined the antimicrobial action of all 116 endophytic fungi isolated from stem barks of $H$. speciosa. A group of 39 strains (33.6\%) displayed antimicrobial activity against Gram-positive bacteria, Gram-negative bacteria, and pathogenic yeasts under the tested conditions. The IDZ values ranged from 11 to $39 \mathrm{~mm}$ (Table 3). In this study, we considered IDZ values smaller than $10 \mathrm{~mm}$ as low active, IDZs between 10 and $20 \mathrm{~mm}$ moderately active, and IDZs greater than $20 \mathrm{~mm}$ as high active [40]. Among the active fungi, 21 were isolated during the RS, while 18 were isolated during the DS. Therefore, the relative frequency of strains with antimicrobial potential was higher in the DS (45\%) than in the RS (27.63\%) (considering the total number of isolated strains in each season). However, strains isolated in the rainy season had a higher antimicrobial potential because they inhibited the growth of at least two pathogen species.

Table 3. Preliminary antimicrobial screening of endophytic fungi from $\mathrm{H}$. speciosa bark isolated in rainy and dry seasons.

\begin{tabular}{|c|c|c|c|c|c|c|c|c|c|c|c|c|}
\hline \multirow[t]{2}{*}{ Code } & \multirow[t]{2}{*}{ Endophytic fungi } & \multirow[t]{2}{*}{ Season } & \multicolumn{10}{|c|}{ Pathogens } \\
\hline & & & $\begin{array}{c}\text { B. } \\
\text { subtilis }\end{array}$ & $\begin{array}{c}E . \\
\text { coli }\end{array}$ & $\begin{array}{c}\text { K. } \\
\text { pneumoniae }\end{array}$ & $\begin{array}{c}P . \\
\text { aeruginosa }\end{array}$ & $\begin{array}{c}P . \\
\text { mirabilis }\end{array}$ & $\begin{array}{c}S . \\
\text { aureus }\end{array}$ & $\begin{array}{c}C . \\
\text { albicans }\end{array}$ & $\begin{array}{c}C . \\
\text { krusei }\end{array}$ & $\begin{array}{c}C . \\
\text { tropicalis }\end{array}$ & $\begin{array}{c}\text { M. } \\
\text { furfur }\end{array}$ \\
\hline FHS012 & A. flavus & R.S. & ++ & ++ & ++ & +++ & ++ & ++ & ++ & - & - & + \\
\hline FHS018 & A. flavus & R.S. & ++ & + & ++ & ++ & ++ & ++ & - & - & - & - \\
\hline FHS019 & A. flavus & R.S. & ++ & ++ & + & ++ & ++ & +++ & - & - & - & - \\
\hline FHS061 & A. niger & R.S. & ++ & ++ & ++ & ++ & ++ & + & - & - & - & + \\
\hline FHS058 & A. niger & R.S. & ++ & ++ & +++ & ++ & ++ & ++ & + & + & - & + \\
\hline FHS042 & C. gloeosporioides & R.S. & + & - & - & ++ & - & - & - & - & - & - \\
\hline FHS051 & F. lateritium & R.S. & ++ & ++ & ++ & + & - & - & - & - & - & - \\
\hline FHS052 & $F$. lateritium & R.S. & ++ & ++ & ++ & + & - & - & - & - & - & - \\
\hline FHS101 & F. solani & R.S. & ++ & ++ & + & + & ++ & ++ & + & - & - & + \\
\hline FHS105 & F. solani & R.S. & ++ & ++ & ++ & ++ & - & ++ & + & - & - & ++ \\
\hline FHS106 & F. solani & R.S. & ++ & ++ & ++ & ++ & +++ & ++ & + & - & - & - \\
\hline FHS109 & F. solani & R.S. & ++ & ++ & + & ++ & + & ++ & + & - & - & + \\
\hline FHS070 & L. theobromae & R.S. & ++ & ++ & ++ & ++ & + & ++ & - & - & - & + \\
\hline FHS073 & L. theobromae & R.S. & ++ & ++ & ++ & ++ & - & + & - & - & - & - \\
\hline FHS115 & M. sterilia & R.S. & + & - & - & + & - & - & - & - & - & - \\
\hline FHS089 & P. fellutanum & R.S. & +++ & ++ & ++ & ++ & - & ++ & - & - & - & + \\
\hline FHS093 & P. fellutanum & R.S. & ++ & ++ & ++ & ++ & - & + & - & - & - & - \\
\hline FHS096 & P. fellutanum & R.S. & + & ++ & ++ & + & - & ++ & - & - & - & - \\
\hline FHS005 & P. archeri & R.S. & ++ & ++ & + & - & ++ & - & - & - & - & - \\
\hline FHS003 & P. archeri & R.S. & ++ & - & - & - & ++ & - & - & - & - & - \\
\hline FHS100 & T. oryzae & R.S. & + & + & - & ++ & - & - & - & - & - & - \\
\hline FHS059 & A. niger & D.S. & ++ & ++ & ++ & ++ & ++ & + & ++ & - & - & - \\
\hline FHS067 & A. niger & D.S. & ++ & + & + & + & - & + & - & - & + & + \\
\hline FHS041 & C. cladosporioides & D.S. & - & - & + & ++ & - & - & - & - & - & - \\
\hline FHS046 & C. gloeosporioides & D.S. & + & - & - & ++ & - & - & - & - & - & - \\
\hline FHS049 & C. gloeosporioides & D.S. & - & - & - & + & - & - & - & - & - & - \\
\hline FHS074 & L. theobromae & D.S. & ++ & ++ & ++ & ++ & - & ++ & - & - & - & - \\
\hline FHS075 & L. theobromae & D.S. & ++ & ++ & + & ++ & - & + & - & - & - & - \\
\hline FHS079 & L. theobromae & D.S. & ++ & + & + & ++ & + & - & - & - & - & - \\
\hline FHS090 & M. elegans & D.S. & + & - & - & - & - & - & - & - & - & - \\
\hline FHS091 & M. elegans & D.S. & + & - & - & - & + & - & - & - & - & - \\
\hline FHS114 & M. sterilia & D.S. & - & ++ & - & - & - & - & - & - & - & - \\
\hline FHS116 & M. sterilia & D.S. & + & - & - & - & - & - & - & - & - & - \\
\hline FHS031 & N. sphaerica & D.S. & ++ & - & - & ++ & ++ & ++ & - & - & - & - \\
\hline FHS032 & N. sphaerica & D.S. & + & + & + & + & + & + & - & - & - & - \\
\hline FHS065 & P. cava & D.S. & - & - & + & + & ++ & ++ & - & - & - & - \\
\hline
\end{tabular}


(Table 3) contd.....

\begin{tabular}{|c|c|c|c|c|c|c|c|c|c|c|c|c|}
\hline \multirow[t]{2}{*}{ Code } & \multirow[t]{2}{*}{ Endophytic fungi } & \multirow[t]{2}{*}{ Season } & \multicolumn{10}{|c|}{ Pathogens } \\
\hline & & & $\begin{array}{c}\text { B. } \\
\text { subtilis }\end{array}$ & $\begin{array}{c}E . \\
\text { coli }\end{array}$ & $\begin{array}{c}K . \\
\text { pneumoniae }\end{array}$ & $\begin{array}{c}P . \\
\text { aeruginosa }\end{array}$ & $\begin{array}{c}P . \\
\text { mirabilis }\end{array}$ & $\begin{array}{c}\text { S. } \\
\text { aureus }\end{array}$ & $\begin{array}{c}C . \\
\text { albicans }\end{array}$ & $\begin{array}{c}\text { C. } \\
\text { krusei }\end{array}$ & $\begin{array}{c}C . \\
\text { tropicalis }\end{array}$ & $\begin{array}{c}\text { M. } \\
\text { furfur }\end{array}$ \\
\hline FHS066 & P. cava & D.S. & + & - & + & + & ++ & ++ & - & - & - & + \\
\hline FHS033 & T. harzianum & D.S. & - & - & - & - & + & - & - & - & - & - \\
\hline FHS037 & T. harzianum & D.S. & - & - & - & + & - & - & - & + & - & - \\
\hline
\end{tabular}

R.S.: Rainy season; D.S.: Dry season; +: $20 \mathrm{~mm}>$ IDZ $10 \mathrm{~mm}$; ++: $30 \mathrm{~mm}>$ IDZ $\geq 20 \mathrm{~mm}$; +++: IDZ $\geq 30 \mathrm{~mm}$; -: IDZ < $10 \mathrm{~mm}$.

Regarding the anti-bacterial activity, all strains isolated in the RS showed the capacity to simultaneously inhibit gram-positive and gram-negative bacteria. Bacillus subtilis was inhibited by all strains isolated during the RS, with more than $80 \%$ presenting IDZ values larger than $20 \mathrm{~mm}$. Similarly, approximately $76 \%$ of the endophytic fungi during this period exhibited IDZ larger values than $20 \mathrm{~mm}$ against $E$. coli. A significant number of endophytic strains were active against $P$. aeruginosa (67\%), K. pneumoniae (62\%), S. aureus (52\%), and P. mirabilis $(43 \%)$. In contrast, the bacteria most effectively inhibited by strains isolated in the dry period were $P$. aeruginosa (38.9\%), followed by $B$. subtilis (33.3\%), E. coli, P. mirabilis, S. aureus (22.2\%), and K. pneumoniae (11.1\%). Finally, only three isolates showed anti-yeast potential. Two strains were effective against C. albicans (A. flavus FHS012 and A. niger FHS059, isolates from the rainy and dry period, respectively) and another strain was active against M. furfur (F. solani FHS105 from the RS). Other studies have also observed the antimicrobial activity of endophytic fungi from the same genera or species of the strains isolated in our work [12, 31, 32, 41, 42]. The isolates designated as M. sterilia were also active against some microorganisms tested, suggesting that antimicrobial potential is independent of the reproductive processes of each isolate, as previously reported [12].

\subsection{MIC and MBC of the Most Active Endophytic Strains}

Eight endophytic fungi isolated from the RS (A. flavus FHS012, A. flavus FHS018, A. niger FHS058, A. niger FHS061, F. solani FHS105, F. solani FHS106, L. theobromae FHS070, and P. fellutanum FHS089) and two isolated from the DS ( $A$. niger FHS059 and L. theobromae FHS074) were fermented in semisolid medium. This selection was based on their performance in the antimicrobial screening (IDZ values $\geq 20 \mathrm{~mm}$ in diameter against the largest number of pathogenic microorganisms tested). Two semi-solid media (corn or rice) were used for fermentation to obtain crude methanolic extracts, for which the MIC and MMC values were determined. The extracts were dissolved in DMSO, and this solvent did not inhibit microbial growth. Control extracts obtained only from the maize and rice media showed no antimicrobial activity.

All endophytic strains produced antimicrobial compounds in both media tested. The MIC values ranged from 19 $\mu \mathrm{g} / \mathrm{mL}$ to $2500 \mu \mathrm{g} / \mathrm{mL}$ (Table 4). Considering the MIC values of all strans, the most inhibited microrganism was $P$. mirabilis with average MIC of $263.3 \mu \mathrm{g} / \mathrm{mL}$ and $382.6 \mu \mathrm{g} / \mathrm{mL}$ using rice and corn based media, respectively $(\mathrm{p}<0.05)$. In fact, most of the best results (MIC $<100 \mu \mathrm{g} / \mathrm{mL}$ ) were observed for extracts obtained from fermentation using rice as a substrate. Regarding the anti-bacterial activity, the most active strains in both medium were: A. niger FHS058 (average MIC values of $149.5 \mu \mathrm{g} / \mathrm{mL}$ and $416.5 \mu \mathrm{g} / \mathrm{mL}$, for rice and corn, respectively), A. niger FHS059 (average MIC values of $217.8 \mu \mathrm{g} / \mathrm{mL}$ and $364.3 \mu \mathrm{g} / \mathrm{mL}$, for rice and corn, respectively), A. niger FHS061 (average MIC values of $292.8 \mu \mathrm{g} / \mathrm{mL}$ and $455.5 \mu \mathrm{g} / \mathrm{mL}$, for rice and corn, respectively). No significant differences were found between their average MIC $(\mathrm{p}>0.05)$. Specifically, when cultivated in rice-based medium, A. niger FHS061 showed an MIC of 19 $\mu \mathrm{g} / \mathrm{mL}$ towards $P$. mirabilis and $39 \mu \mathrm{g} / \mathrm{mL}$ against $S$. aureus; A. niger FHS058 presented MIC values of $78 \mu \mathrm{g} / \mathrm{mL}$ and $39 \mu \mathrm{g} / \mathrm{mL}$ against these same bacteria, respectively. The extract from $F$. solani FHS106 cultivated in rice medium showed an MIC of $78 \mu \mathrm{g} / \mathrm{mL}$ for $K$. pneumoniae.

Table 4. Antimicrobial activity of methanolic extracts obtained from semi-solid fermentation of endophytic fungi from $H$. speciosa bark isolated in rainy and dry seasons.

\begin{tabular}{|c|c|c|c|c|c|c|c|c|c|c|c|c|c|c|c|c|c|c|}
\hline \multirow{3}{*}{ Code } & \multirow{3}{*}{$\begin{array}{c}\text { Endophytic } \\
\text { fungi }\end{array}$} & \multirow{3}{*}{ Substrate } & \multicolumn{16}{|c|}{ Pathogens } \\
\hline & & & \multicolumn{2}{|c|}{ B. subtilis } & \multicolumn{2}{|c|}{ E. coli } & \multicolumn{2}{|c|}{\begin{tabular}{|c|} 
K. \\
pneumoniae
\end{tabular}} & \multicolumn{2}{|c|}{\begin{tabular}{c|c|}
$P$. \\
aeruginosa
\end{tabular}} & \multicolumn{2}{|c|}{ P. mirabilis } & \multicolumn{2}{|c|}{ S. aureus } & \multicolumn{2}{|c|}{ C. albicans } & \multicolumn{2}{|c|}{ M. furfur } \\
\hline & & & MIC $^{1}$ & $\mathrm{CMM}^{1}$ & MIC' & $\mathbf{C M M}^{1}$ & MIC ${ }^{1}$ & $\mathbf{C M M}^{1}$ & MIC ${ }^{1}$ & $\mathrm{CMM}^{1}$ & MIC & $\mathrm{CMM}^{1}$ & MIC & $\mathrm{CMM}^{1}$ & MIC ${ }^{1}$ & $\mathrm{CMM}^{1}$ & MIC & $\mathrm{CMM}^{1}$ \\
\hline \begin{tabular}{|l|} 
FHS012 \\
\end{tabular} & A. flavus & Rice & 1250 & 5000 & 1250 & $>5000$ & 1250 & 5000 & 1250 & 2500 & 312 & 2500 & 1250 & $>5000$ & 2500 & $>5000$ & 1250 & $>5000$ \\
\hline \begin{tabular}{|l|} 
FHS018 \\
\end{tabular} & A. flavus & ice & 1250 & 5000 & 1250 & $>5000$ & 1250 & $>5000$ & 1250 & 2500 & 312 & 2500 & 2500 & $>5000$ & 2500 & $>5000$ & 2500 & 5000 \\
\hline FHS058 & A. niger & & 156 & 625 & 156 & 2500 & 312 & 1250 & 156 & 1250 & 78 & 625 & 39 & 312 & 2500 & $>5000$ & 2500 & 5000 \\
\hline \begin{tabular}{|l|} 
FHS059 \\
\end{tabular} & A. niger & Rice & 156 & 1250 & 625 & 5000 & 625 & 1250 & 156 & 2500 & 39 & 625 & 156 & 625 & 1250 & $>5000$ & 2500 & $>5000$ \\
\hline
\end{tabular}


(Table 4) contd....

\begin{tabular}{|c|c|c|c|c|c|c|c|c|c|c|c|c|c|c|c|c|c|c|}
\hline \multirow{3}{*}{ Code } & \multirow{3}{*}{$\begin{array}{c}\text { Endophytic } \\
\text { fungi }\end{array}$} & \multirow{3}{*}{ Substrate } & \multicolumn{16}{|c|}{ Pathogens } \\
\hline & & & \multicolumn{2}{|c|}{ B. subtilis } & \multicolumn{2}{|c|}{ E. coli } & \multicolumn{2}{|c|}{\begin{tabular}{|c|} 
K. \\
pneumoniae
\end{tabular}} & \multicolumn{2}{|c|}{$\begin{array}{c}P . \\
\text { aeruginosa }\end{array}$} & \multicolumn{2}{|c|}{ P. mirabilis } & \multicolumn{2}{|c|}{ S. aureus } & \multicolumn{2}{|c|}{ C. albicans } & \multicolumn{2}{|c|}{ M. furfur } \\
\hline & & & MIC $^{1}$ & $\mathrm{CMM}^{1}$ & MIC $^{1}$ & $\mathrm{CMM}^{1}$ & MIC $^{1}$ & $\mathbf{C M M}^{1}$ & MIC $^{1}$ & $\mathrm{CMM}^{1}$ & MIC $^{1}$ & $\mathrm{CMM}^{1}$ & MIC $^{1}$ & $\mathrm{CMM}^{1}$ & MIC $^{1}$ & $\mathrm{CMM}^{1}$ & MIC $^{1}$ & $\mathrm{CMM}^{1}$ \\
\hline FHS061 & A. niger & Rice & 156 & 1250 & 312 & 5000 & 625 & 2500 & 156 & 1250 & 19 & 625 & 39 & 312 & 2500 & 5000 & 2500 & $>5000$ \\
\hline FHS105 & F. solani & Rice & 1250 & 5000 & 625 & $>5000$ & 78 & 625 & 625 & 5000 & 312 & 5000 & 625 & 1250 & 312 & 1250 & 625 & 1250 \\
\hline FHS106 & F. solani & Rice & 1250 & $>5000$ & 625 & $>5000$ & 156 & 625 & 625 & 5000 & 312 & 5000 & 625 & 5000 & 625 & 1250 & 625 & 2500 \\
\hline FHS070 & $\begin{array}{c}\text { L. } \\
\text { theobromae }\end{array}$ & Rice & 1250 & 5000 & 1250 & $>5000$ & 1250 & 2500 & 312 & 5000 & 312 & $>5000$ & 1250 & $>5000$ & 625 & 2500 & 1250 & 5000 \\
\hline \begin{tabular}{|l|} 
FHS074 \\
\end{tabular} & $\begin{array}{c}L . \\
\text { theobromae }\end{array}$ & Rice & 1250 & 5000 & 2500 & $>5000$ & 1250 & 5000 & 625 & 5000 & 312 & $>5000$ & 1250 & 5000 & 625 & 5000 & 2500 & $>5000$ \\
\hline FHS089 & $\begin{array}{c}P . \\
\text { fellutanum } \\
\end{array}$ & Rice & 1250 & $>5000$ & 625 & 5000 & 1250 & $>5000$ & 625 & $>5000$ & 625 & 5000 & 1250 & $>5000$ & 1250 & $>5000$ & 2500 & $>5000$ \\
\hline FHS012 & A. flavus & Corn & 1250 & 5000 & 1250 & $>5000$ & 1250 & $>5000$ & 1250 & $>5000$ & 625 & 5000 & 1250 & 5000 & 2500 & $>5000$ & 1250 & $>5000$ \\
\hline FHS018 & A. flavus & Corn & 1250 & $>5000$ & 2500 & $>5000$ & 1250 & $>5000$ & 1250 & 5000 & 625 & 5000 & 1250 & 5000 & 1250 & 5000 & 2500 & 5000 \\
\hline FHS058 & A. niger & Corn & 625 & 2500 & 625 & 2500 & 625 & 5000 & 312 & 2500 & 156 & 1250 & 156 & 625 & 2500 & $>5000$ & 2500 & 5000 \\
\hline FHS059 & A. niger & Corn & 625 & 2500 & 312 & 2500 & 625 & 2500 & 312 & 5000 & 156 & 1250 & 156 & 1250 & 2500 & 5000 & 1250 & 5000 \\
\hline FHS061 & A. niger & Corn & 312 & 1250 & 312 & 5000 & 1250 & 2500 & 156 & 2500 & 78 & 625 & 625 & 1250 & 1250 & $>5000$ & 1250 & 5000 \\
\hline FHS105 & F. solani & Corn & 625 & 1250 & 1250 & $>5000$ & 156 & 625 & 1250 & $>5000$ & 625 & $>5000$ & 312 & 1250 & 312 & 1250 & 2500 & $>5000$ \\
\hline FHS106 & F. solani & Corn & 625 & 1250 & 2500 & $>5000$ & 156 & 1250 & 1250 & $>5000$ & 312 & $>5000$ & 1250 & 2500 & 312 & 2500 & 625 & 1250 \\
\hline FHS070 & $\begin{array}{c}L . \\
\text { theobromae } \\
\end{array}$ & Corn & 2500 & 5000 & 1250 & 5000 & 2500 & 5000 & 625 & $>5000$ & 312 & 5000 & 1250 & 5000 & 1250 & $>5000$ & 1250 & 2500 \\
\hline FHS074 & $\begin{array}{c}\text { L. } \\
\text { theobromae }\end{array}$ & Corn & 2500 & 5000 & 1250 & 5000 & 2500 & $>5000$ & 625 & $>5000$ & 312 & $>5000$ & 1250 & $>5000$ & 625 & 5000 & 1250 & 5000 \\
\hline FHS089 & $\begin{array}{c}P . \\
\text { fellutanum }\end{array}$ & Corn & 1250 & 5000 & 1250 & 5000 & 1250 & 5000 & 1250 & $>5000$ & 625 & 5000 & 1250 & $>5000$ & 2500 & $>5000$ & 2500 & $>5000$ \\
\hline
\end{tabular}

MIC: minimum inhibitory concentration; MMC: minimum microbicide concentration; ${ }^{1}$ Results are expressed in $\mu \mathrm{g} / \mathrm{mL}$.

In corn media, A. niger FHS061 had an MIC of $78 \mu \mathrm{g} / \mathrm{mL}$ against $P$. mirabilis. All of these extracts exhibited bacteriostatic activity (MMC/MIC ratio > 4). Some strains exhibited MIC values of $156 \mu \mathrm{g} / \mathrm{mL}$ against $B$. subtilis (FHS058, FHS059, and FHS061 in rice medium), E. coli (FHS058 in rice medium), K. pneumoniae (FHS106 in rice medium; FHS105 and FHS106 in corn medium), P. aeroginosa (FHS058, FHS059, and FHS061 in rice medium; FHS061 in corn medium), and S. aureus (FHS058 and FHS059 in corn).

Regarding antifungal action, the strains showed low actitivity against $C$. albicans or $M$. furfur. The best activity against $C$. albicans was observed for the endophytic strains $F$. solani FHS105 (MIC values of $312 \mu \mathrm{g} / \mathrm{mL}$ and in both medium) and F. solani FHS106 (MIC values of $312 \mu \mathrm{g} / \mathrm{mL}$ and $625 \mu \mathrm{g} / \mathrm{mL}$, in corn and rice medium, respectively). These two strains also exhibited the lower MIC values against $M$. furfur (MIC values of $625 \mu \mathrm{g} / \mathrm{mL}$ ).

It is well-known that the production of bioactive metabolites depends greatly on the culture medium on which the fungus is grown $[8,43,44]$. In the present study, the best antimicrobial activity was observed when rice was used as a substrate. Recently, our group showed similar results with endophytic fungi isolated from Indigofera suffruticosa [12]. In addition to the chemical differences between the two media, interstitial areas were formed between the grains in the rice medium. These areas may promote better substrate utilization in this medium.

\section{CONCLUSION}

Our results demonstrate the diversity of endophytic fungi in $H$. speciosa bark and importance of these microorganisms as promising targets for bioactive compounds with antimicrobial potential. The frequency of colonization of endophytes in H. speciosa bark was higher during the rainy season, although diversity was similar in both periods. Crude extracts of the endophytes obtained from fermentation in rice medium showed higher antimicrobial activity. The best results were observed for A. niger FHS058, A. niger FHS061, and F. solani FHS106. Therefore, the isolates described above constitute attractive targets for other studies to optimize the culture conditions for the production of bioactive compounds, as well as their chemical characterization. These compounds may be use directly or as a basis for the synthesis of new agents with antimicrobial activity.

\section{ETHICS APPROVAL AND CONSENT TO PARTICIPATE}

Not applicable. 


\section{HUMAN AND ANIMAL RIGHTS}

No Animals/Humans were used for studies that are base of this research.

\section{CONSENT FOR PUBLICATION}

Not applicable.

\section{CONFLICT OF INTEREST}

The authors declare no conflict of interest, financial or otherwise.

\section{ACKNOWLEDGEMENTS}

The authors express their gratitude for the following Brazilian agencies for the financial support: Fundação de Amparo à Ciência e Tecnologia do Estado de Pernambuco (FACEPE), Coordenacão de Aperfeiçoamento de Pessoal de Nível Superior (CAPES), Conselho Nacional de Desenvolvimento Científico e Tecnológico (CNPq).

\section{REFERENCES}

[1] Barriere SL. Clinical, economic and societal impact of antibiotic resistance. Expert Opin Pharmacother 2015; 16(2): 151-3. [http://dx.doi.org/10.1517/14656566.2015.983077] [PMID: 25483564]

[2] Martins A, Hunyadi A, Amaral L. Mechanisms of resistance in bacteria: An evolutionary approach. Open Microbiol J 2013; 7: 53-8. [http://dx.doi.org/10.2174/1874285801307010053] [PMID: 23560029]

[3] Tillotson GS, Zinner SH. Burden of antimicrobial resistance in an era of decreasing susceptibility. Expert Rev Anti Infect Ther 2017; 15(7): 663-76.

[http://dx.doi.org/10.1080/14787210.2017.1337508] [PMID: 28580804]

[4] Blair JM, Webber MA, Baylay AJ, Ogbolu DO, Piddock LJ. Molecular mechanisms of antibiotic resistance. Nat Rev Microbiol 2015; 13(1): 42-51. [http://dx.doi.org/10.1038/nrmicro3380] [PMID: 25435309]

[5] Millar MR. The choice to travel: Health tourists and the spread of antibiotic resistance. Public Health Ethics 2015; 8(8): 238-45. [http://dx.doi.org/10.1093/phe/phv003]

[6] Hall CW, Mah TF. Molecular mechanisms of biofilm-based antibiotic resistance and tolerance in pathogenic bacteria. FEMS Microbiol Rev 2017; 41(3): 276-301.

[http://dx.doi.org/10.1093/femsre/fux010] [PMID: 28369412]

[7] Deshmukh SK, Verekar SA, Bhave SV. Endophytic fungi: A reservoir of antibacterials. Front Microbiol $2015 ; 5: 715$. [http://dx.doi.org/10.3389/fmicb.2014.00715] [PMID: 25620957]

[8] Jia M, Chen L, Xin HL, et al. A friendly relationship between endophytic fungi and medicinal plants: A systematic review. Front Microbiol 2016; 7: 906.

[http://dx.doi.org/10.3389/fmicb.2016.00906] [PMID: 27375610]

[9] Gokhale M, Gupta D, Gupta U, Faraz R, Sandhu SS. Patents on endophytic fungi. Recent Pat Biotechnol 2017; 11(2): 120-40. [http://dx.doi.org/10.2174/1872208311666170215151834] [PMID: 28215141]

[10] Higgins KL, Arnold AE, Coley PD, Kursar TA. Communities of fungal endophytes in tropical forest grasses: Highly diverse host-and habitat generalists characterized by strong spatial structure. Fungal Ecol 2014; 8: 11. [http://dx.doi.org/10.1016/j.funeco.2013.12.005]

[11] Santos IP, Bezerra JD, de Souza-Motta CM, da Silva Cavalcanti M, Menezes Lima VL. Endophytic mycobiota from leaves of Indigofera suffruticosa Miller (Fabaceae): The relationship between seasonal change in Atlantic Coastal Forest and tropical dry forest (Caatinga), Brazil. Afr J Microbiol Res 2015; 9: 9.

[12] Dos Santos IP, da Silva LC, da Silva MV, de Araújo JM, Cavalcanti MdaS, Lima VL. Antibacterial activity of endophytic fungi from leaves of Indigofera suffruticosa Miller (Fabaceae). Front Microbiol 2015; 6: 350. [PMID: 25999918]

[13] Negreiros de Carvalho PL, Silva EdeO, Chagas-Paula DA, Hortolan Luiz JH, Ikegaki M. Importance and implications of the production of phenolic secondary metabolites by endophytic fungi: A mini-review. Mini Rev Med Chem 2016; 16(4): $259-71$. [http://dx.doi.org/10.2174/1389557515666151016123923] [PMID: 26471971]

[14] Silva TF, Coelho MR, Vollú RE, et al. Bacterial community associated with the trunk latex of Hancornia speciosa Gomes (Apocynaceae) grown in the northeast of Brazil. Antonie van Leeuwenhoek 2011; 99(3): 523-32. [http://dx.doi.org/10.1007/s10482-010-9520-7] [PMID: 20960060]

[15] Jimenez HJ, Martins LS, Montarroyos AV, Silva Junior JF, Alzate-Marin AL, Moraes Filho RM. Genetic diversity of the neotropical tree hancornia speciosa gomes in natural populations in Northeastern Brazil. Genet Mol Res 2015; 14(4): 17749-57.

[http://dx.doi.org/10.4238/2015.December.21.48] [PMID: 26782420] 
[16] Costa ES, Hiruma-Lima CA, Lima EO, et al. Antimicrobial activity of some medicinal plants of the Cerrado, Brazil. Phytother Res 2008; 22(5): 705-7. [http://dx.doi.org/10.1002/ptr.2397] [PMID: 18350520]

[17] Ferreira HC, Serra CP, Endringer DC, Lemos VS, Braga FC, Cortes SF. Endothelium-dependent vasodilation induced by Hancornia speciosa in rat superior mesenteric artery. Phytomedicine : Int J Phyth Phytopharm 2007; 14(7-8): 473-8.

[18] Moraes TdeM, Rodrigues CM, Kushima H, et al. Hancornia speciosa: Indications of gastroprotective, healing and anti-Helicobacter pylori actions. J Ethnopharmacol 2008; 120(2): 161-8. [http://dx.doi.org/10.1016/j.jep.2008.08.001] [PMID: 18761076]

[19] Pereira AC, Pereira AB, Moreira CC, et al. Hancornia speciosa gomes (Apocynaceae) as a potential anti-diabetic drug. J Ethnopharmacol 2015; 161: 30-5.

[http://dx.doi.org/10.1016/j.jep.2014.11.050] [PMID: 25500300]

[20] Santos UP, Campos JF, Torquato HF, et al. Antioxidant, antimicrobial and cytotoxic properties as well as the phenolic content of the extract from hancornia speciosa gomes. 2016; 11: p. (12)e0167531.

[21] Geller FC, Teixeira MR, Pereira AB, et al. Evaluation of the wound healing properties of Hancornia speciosa Leaves. Phytother Res 2015; 29(12): 1887-93.

[http://dx.doi.org/10.1002/ptr.5438] [PMID: 26344935]

[22] Marinho DG, Alviano DS, Matheus ME, Alviano CS, Fernandes PD. The latex obtained from Hancornia speciosa gomes possesses antiinflammatory activity. J Ethnopharmacol 2011; 135(2): 530-7. [http://dx.doi.org/10.1016/j.jep.2011.03.059] [PMID: 21463669]

[23] Torres-Rêgo M, Furtado AA, Bitencourt MA, et al. Anti-inflammatory activity of aqueous extract and bioactive compounds identified from the fruits of Hancornia speciosa Gomes (Apocynaceae). BMC Complement Altern Med 2016; 16: 275. [http://dx.doi.org/10.1186/s12906-016-1259-x] [PMID: 27496015]

[24] Penido AB, De Morais SM, Ribeiro AB, et al. Medicinal plants from northeastern brazil against alzheimer's disease. Evidence-based complementary and alternative medicine : eCAM 2017; 1753673

[25] Morton FJ, Smith G. The genera scopulariopsis bainier, microascus zukal and doratomyces corda. Mycological papers 1963; 86: 1-96.

[26] Ellis MB. Dematiaceous Hyphomycetes. Commonwealth Mycological Institute: Kew, UK 1971.

[27] Ellis MB. More Dematiaceous Hyphomycetes. Commonwealth Mycological Institute: Kew, UK 1976.

[28] Sutton BC. The Coelomycetes: Fungi imperfecti with pycnidia, acervuli and stromata. Commonwealth Mycological Institute: Kew, U.K. 1980 .

[29] Barnett HL, Hunter BB. Illustrated genera of imperfect fungi. $4^{\text {th }}$ ed. American Phytopathological Society: Minnesota, USA 1987.

[30] Hanlin RT. Illustrated genera of Ascomycetes. $2^{\text {nd }}$ ed. American Phytopathological Society: Minnesota, USA 2000.

[31] Xing X, Guo S, Fu J. Biodiversity and distribution of endophytic fungi associated with Panax quinquefolium L. cultivated in a forest reserve. Symbiosis 2010; 51: 151 . [http://dx.doi.org/10.1007/s13199-010-0062-6]

[32] Siqueira VM, Conti R, Araújo JM, Souza-Motta CM. Endophytic fungi from the medicinal plant Lippia sidoides Cham. and their antimicrobial activity. Symbiosis $2011 ; 53(7): 89$. [http://dx.doi.org/10.1007/s13199-011-0113-7]

[33] González-Teuber M. The defensive role of foliar endophytic fungi for a South American tree. AoB Plants 2016; 8: 8. [http://dx.doi.org/10.1093/aobpla/plw050] [PMID: 27339046]

[34] Lugtenberg BJ, Caradus JR, Johnson LJ. Fungal endophytes for sustainable crop production. FEMS Microbiol Ecol 2016; $92(12)$ : 194. [http://dx.doi.org/10.1093/femsec/fiw194] [PMID: 27624083]

[35] Banerjee D. Endophytic fungal diversity in tropical and subtropical plants. Res J Microbiol 2011; 6: 9.

[36] Su YY, Guo LD, Hyde KD. Response of endophytic fungi of Stipa grandis to experimental plant function group removal in Inner Mongolia steppe. Fungal Divers 2010; 43: 93-101.

[http://dx.doi.org/10.1007/s13225-010-0040-6]

[37] Mishra VK, Singh G, Passari AK, Yadav MK, Gupta VK, Singh BP. Distribution and antimicrobial potential of endophytic fungi associated with ethnomedicinal plant melastoma malabathricum L. J Environ Biol 2016; 37(2): 229-37. [PMID: 27097442]

[38] Singh DK, Sharma VK, Kumar J, et al. Diversity of endophytic mycobiota of tropical tree Tectona grandis Linn.f.: Spatiotemporal and tissue type effects. Sci Rep 2017; 7(1): 3745 .

[http://dx.doi.org/10.1038/s41598-017-03933-0] [PMID: 28623306]

[39] Arnold AE, Mejía LC, Kyllo D, et al. Fungal endophytes limit pathogen damage in a tropical tree. Proc Natl Acad Sci USA 2003; 100(26): 15649-54.

[http://dx.doi.org/10.1073/pnas.2533483100] [PMID: 14671327] 
[40] Wang FW, Jiao RH, Cheng AB, Tan SH, Song YC. Antimicrobial potentials of endophytic fungi residing in quercus variabilis and brefeldin a obtained from Cladosporium sp. World J Microbiol Biotechnol 2007; 23 : 5. [http://dx.doi.org/10.1007/s11274-006-9195-4]

[41] Hoffman AM, Mayer SG, Strobel GA, et al. Purification, identification and activity of phomodione, a furandione from an endophytic Phoma species. Phytochemistry 2008; 69(4): 1049-56. [http://dx.doi.org/10.1016/j.phytochem.2007.10.031] [PMID: 18070629]

[42] Chen XM, Dong HL, Hu KX, Sun ZR, Chen JA, Guo SX. Diversity and antimicrobial and plant-growth-promoting activities of endophytic fungi in Dendrobium loddigesii Rolfe. J Plant Growth Regul 2010; 29: 10. [http://dx.doi.org/10.1007/s00344-010-9139-y]

[43] Masi M, Maddau L, Linaldeddu BT, Scanu B, Evidente A, Cimmino A. Bioactive metabolites from pathogenic and endophytic fungi of forest trees. Curr Med Chem 2017; 24: 17 [http://dx.doi.org/10.2174/0929867324666170314145159] [PMID: 28292240]

[44] Vasundhara M, Kumar A, Reddy MS. Molecular approaches to screen bioactive compounds from endophytic fungi. Front Microbiol 2016; 7: 1774.

[http://dx.doi.org/10.3389/fmicb.2016.01774] [PMID: 27895623]

\section{(C) 2017 Chagas et al.}

This is an open access article distributed under the terms of the Creative Commons Attribution 4.0 International Public License (CC-BY 4.0), a copy of which is available at: https://creativecommons.org/licenses/by/4.0/legalcode. This license permits unrestricted use, distribution, and reproduction in any medium, provided the original author and source are credited. 